Nukhet Veziroğlu Akovalı

Aynur Camkiran

Pinar Zeyneloğlu

Atilla Sezgin

Arash Pirat

Gülnaz Arslan

\title{
Koroner Arter Baypas Greftleme Cerrahisi Geçiren Erişkinlerde Uzamış Mekanik Ventilasyonun Önbelirleyicileri
}

\author{
Predictors of Prolonged Mechanical Ventilation for \\ Adult Patients Undergoing Coronary Artery Bypass \\ Grafting Surgery
}

Geliș Tarihi/Received: 21.09.2012

Kabul Tarihi/Accepted: 08.03.2013

Türk Yoğun Bakım Derneği Dergisi, Galenos Yayınevi

tarafından basılmıştır.

Journal of the Turkish Society of Intensive Care, published by Galenos Publishing. ISNN: 1300-5804

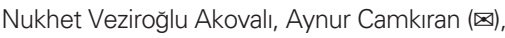
Pınar Zeyneloğlu, Arash Pirat, Gülnaz Arslan Başkent Üniversitesi Tıp Fakültesi Hastanesi, Anesteziyoloji Anabilim Dalı, Ankara, Türkiye

Atilla Sezgin

Başkent Üniversitesi Tıp Fakültesi Hastanesi, Kalp Damar Cerrahisi Anabilim Dalı, Ankara, Türkiye

E-posta: acamkiran@gmail.com

Tel.: +90 31221268 68/1919-20-46
ÖZET Amaç: Bu çalıșmanın amacı koroner arter baypas greftleme (KABG) cerrahisi geçiren hastaların perioperatif verilerini inceleyerek uzamış mekanik ventilasyonun önbelirleyicilerini saptamaktır.

Gereç ve Yöntem: Bașkent Üniversitesi Klinik Araştırma Kurul onayı alındıktan sonra Aralık 2004 ve Aralık 2007 tarihleri arasında KABG cerrahisi geçiren, mekanik ventilasyon ihtiyacı $>24$ saat olan hastalar Grup I'e ( $n=22),<24$ saat olanlar Grup II'ye $(n=463)$ dahil edildi. Bulgular: Eşlik eden hastalıklar açısından Grup I'de kronik böbrek yetmezliği ve geçirilmiş serebrovasküler olay (SVO) varlığının Grup II'den fazla olduğu saptandı ( $p<0,01)$. Grup II ile karşılaştırıldığında Grup I'de preoperatif kan üre azotu, kreatinin, aspartat aminotransferaz değerleri daha yüksek, albümin ve sodyum değerleri daha düşük bulundu (sırasıyla $p<0,01, p<0,01, p=0,02, p=0,01$ ve $p<0,01)$. Grup I'de Grup II'ye göre anestezi, cerrahi ve kardiyopulmoner baypas (KPB) süreleri anlamlı olarak uzun bulundu (hepsi için $p<0,01$ ). Postoperatif mekanik ventilasyon intiyac $>24$ saat olan Grup I'deki hastalarda rektal sıcaklık ve $\mathrm{O} 2$ satürasyonunda düşme daha sık görüldü (sırasıyla $p<0,01, p=0,02$ ). Grup I'in intraoperatif kardiyopulmoner resüsitasyon gereksinimi, intraaortik balon pompası kullanımı, vazopressör ve ultrafiltrasyon intiyacının Grup II'den fazla olduğu saptandı (sırasıyla $p<0,01, p<0,01, p=0,02$ ve $p=0,02$ ). Reeksplorasyon gereksinimi Grup I'de fazla bulundu $(p<0,01)$. Postoperatif ilk ekstübasyona kadar geçen dönemde opioid, sedatif ve kas gevşetici kullanımının da Grup I'de fazla olduğu görüldü (sırasıyla $p=0,02$, $p<0,01$ ve $p=0,01)$. Grup I'de postoperatif taze donmus plazma (TDP) ve tam kan kullanımı anlamlı olarak fazla bulundu (sırasıyla $p<0,01$ ve $p=0,03$ ). Hastaların postoperatif sistemik komplikasyon varlığı (Grup I: \%35, Grup II: \%5,2, $p<0,01$ ) ile cerrahi sırasında ve postoperatif 48 saat içindeki mortaliteleri (Grup I: \%22,7, Grup II: \%2,7, p<0,01) Grup I'de yüksek bulundu. Sonuç: Calıșmamızda KABG sonrası preoperatif SVO varlığı, KPB süresi, intraoperatif O2 satürasyonunda düșme, postoperatif TDP ve sedatif kullanımının çoklu regresyon analizi sonucunda uzamış mekanik ventilasyon için güçlü önbelirleyiciler olduğu saptanmıştır.

Anahtar Kelimeler: Koroner arter baypas greftleme cerrahisi, uzamış mekanik ventilasyon

SUMMARY Objective: The objective of this study was to identify predictors of prolonged mechanical ventilation for those who had coronary artery bypass grafting (CABG) surgery, by evaluating their perioperative data. Material and Method: Five hundred consecutive patients who had CABG surgery between December 2004 and December 2007 were retrospectively evaluated after the approval of Baskent University Clinical Studies Committee. Patients requiring mechanical ventilation for $\geq 24$ hours ( $n=22$ ) were included in Group I and those requiring ventilation for < 24 hours ( $n=463$ ) were included in Group II. Results: Subjects' perioperative findings as a predictor for prolonged mechanical ventilation were analyzed by univariate and multivariate regression analysis. The presence of chronic renal failure and cerebrovascular 
accident (CVA) were higher in Group I when compared to Group II $(p<0.01)$. It was also noted that patients in Group I who needed more than twenty-four hours of postoperative mechanical ventilation received higher rates of emergency surgery than patients in Group II. Preoperative blood urea nitrogen, creatinine, aspartate aminotransferase levels were higher, albumin and sodium levels were lower in Group I when compared to Group II ( $p<0.01, p<0.01$, $p=0.02, p=0.01$, and $p<0.01$ respectively). Anesthesia, surgery and CPB durations were significantly longer for Group I compared to Group II ( $p<0.01$ for all). Those who needed more than twenty-four hours of mechanical ventilation in Group I had significantly lower rectal temperatures and $\mathrm{O} 2$ saturation $(\mathrm{p}=0.02)$. The need for intraoperative cardiopulmonary resuscitation, the use of intra-aortic balloon pump, and the need for vasopressors and ultrafiltration were higher in Group I when compared to Group II ( $p<0.01, p<0.01$, $p=0.02$ and $p=0.02$ respectively). The need for reexploration was higher in Group I $(p<0.01)$. Also, Group I had higher levels of opioid, sedative and muscle relaxant usage till postoperative first extubation $(p=0.02, p=0.01$, and $p=0.01$ respectively). Group I had significantly higher requirements of postoperative fresh frozen plasma (FFP) and whole blood ( $p<0.01$ and $p=0.03$ respectively). Presence of postoperative systemic complications (Group I: 35\%, Group
II: $5.2 \%, p<0.01$ ) along with intraoperative and postoperative mortality rates within fortyeight hours (Group I: 22.7\%, Group II: \%2.7\%, $p<0.01$ ), were found to be higher in the group that required mechanical ventilation longer than twenty-four hours.

Conclusion: In conclusion, by employing multivariate regression analysis preoperative CVA presence, CPB duration, the decreased levels of intraoperative $\mathrm{O} 2$ saturation, post CABG usage of FFP plasma and sedatives were identified as statistically significant predictors of prolonged mechanical ventilation

Key Words: Coronary artery bypass grafting surgery, prolonged mechanical ventilation

\section{Giriş}

Koroner arter baypas greftleme (KABG) cerrahisinden sonra yoğun bakıma alınan hastalar aşağıda belirtilen koşullar sağlanınca ekstübe edilmektedir. Bu koşullar; plevral ve mediastinal drenlerden gelen kanama miktarının <100 ml/ saat olması, idrar çıkışının >0,5ml/kg/saat olması, yüksek doz vazopressör veya inotrop intiyacı olmadan, intraaortik balon pompası ve mekanik olarak dolaşımı destekleyen cihazlara ihtiyaç olmadan hemodinamik stabilitenin sağlanması, yaşamı tehdit eden ciddi aritminin bulunmaması, $\mathrm{FiO} 2<0,5$ iken PaO2'nin >100 olması, hasta uyanık, koopere ve herhangi fokal veya global nörolojik defisit bulgusunun olmaması, vücut sıcaklığının $>35.5^{\circ} \mathrm{C}$ olması ve kan gazı değerlerinde inatçı veya kötüye gidiş gösteren metabolik asidoz tablosunun bulunmaması şeklinde sıralanabilmektedir (1-5).

Postoperatif mekanik ventilasyon ihtiyacının 24 saatten uzun olma insidansı ilk KABG cerrahisinde \%5,5 iken reoperasyon sonrası \%10,5 civarındadır (1). Ekstübasyon başarısızlığı veya uzamış mekanik ventilasyon tanımı için standart bir süre bildirilmemekle birlikte eski yayınlarda 2-7 güne kadar, yeni çalışmalarda 6-24 saate uzamaktadır (2-6).

Erken ekstübasyonun en önemli klinik avantajları arasında pozitif basınçlı mekanik ventilasyonun olumsuz etkilerini ve enfeksiyon insidansını azaltması yanında erken ambulasyon ve hasta konforunu sağlaması sayılabilir. Diğer yandan, uzamış mekanik ventilasyon hastane masraflarını artırmakla birlikte artmış havayolu ve akciğer travmasına, endotrakeal aspirasyona bağlı artmış strese, azalmış kardiyak debi ve renal perfüzyona da neden olmaktadır $(7,8)$.

Bu çalışmanın amacı KABG cerrahisi geçiren hastaların perioperatif verilerini inceleyerek uzamış mekanik ventilasyon için olası önbelirleyicileri saptamaktır.

\section{Gereç ve Yöntem}

Başkent Üniversitesi Klinik Araştırma Kurul onayı (KA07/04, 06.03.2007) alındıktan sonra Aralık 2004 ve Aralık
2007 tarihleri arasında KABG cerrahisi geçiren hastalar geriye dönük olarak değerlendirildi. Dosyaları incelenen 500 hastadan 15'inin verileri yetersiz olduğundan çalışmaya alınmadı. Hastalar, mekanik ventilasyon ihtiyacı 24 saatten uzun olanlar (Grup I, n=22) ve 24 saatten kısa olanlar olarak (Grup II, n=463) iki gruba ayrıldılar.

\section{Hasta Popülasyonu}

KABG cerrahisi yapılmış tüm hastalar çalışmaya dahil edildi. Kombine kapak ve koroner cerrahi uygulanan hastalar ile KPB kullanılmadan KABG cerrahisi yapılan hastalar çalışma dışı tutuldu.

\section{Anestezi Uygulaması}

Ameliyat odasına alınan bütün hastalar 5 kanallı EKG, nabız oksimetresi ve invazif olmayan kan basıncı ölçümü ile monitörize edildi. Periferik damar yolu açılmasını takiben anestezi indüksiyonunda etomidat (Etomidat Lipuro®) 0,1-0,3 $\mathrm{mg} / \mathrm{kg}$, fentanil sitrat (Fentanyl®) $5-10 \mathrm{mcg} / \mathrm{kg}$, veküronyum bromür (Norcuron®) 0,1 mg/kg verildi. Anestezi idamesi için fentanil 10 mcg/kg/saat ve \%50 oksijen-hava karışımı içinde izofluran (Forane®) \%0,5-1,5 kullanıldı. Ameliyat boyunca hastalar volüm kontrol modunda tidal volüm 6-8 ml/kg ve inspirasyon ekspirasyon oranı 1:2 olacak şekilde 0-5 cmH2O PEEP uygulanarak ventile edilip, solunum sayısı end-tidal CO2 değeri 30-40 mmHg olacak şekilde ayarlandı. Arter takılması ve santral venöz kanülasyonu takiben nazogastrik ve idrar sondası ile nazofaringeal ve rektal sıcaklık probları yerleştirildi. Ameliyatın başlamasının hemen ardından hastanın kan basıncının bazal kan basıncı değeri $\pm \% 20$ olacak şekilde inotropik ve vazodilatör desteği ayarlandı. Kullanılacak greftin çıkarılmasına başlanırken 4 mg/kg heparin ile antikoagülasyon sağlandı.

\section{Kardiyopulmoner Baypas}

Pompa başlangıç solüsyonu hastanın hematokrit değeri \%26-28 olacak şekilde laktatlı Ringer, taze donmuş plazma (TDP), eritrosit süspansiyonu (ES) ve heparinle hazırlandı. KPB sırasında hastaya uygulanacak distal greft sayısıyla bağlantılı olarak sistemik hipotermi $28-30{ }^{\circ} \mathrm{C}$ olacak şekilde ayarlandı. KPB esnasında membran oksijenatör (Cobe Optima XP) 
kullanılıp, perfüzyon hızı 50-70 ml/kg/dk ve ortalama arteriyel basınç 55-75mmHg olacak şekilde ayarlandı. KPB süresince alfa-stat pH stratejisi uygulandı. Aortanın klemplenmesini takiben miyokardın korunması soğuk potasyumlu kristaloid kardiyopleji ile sağlandı.

\section{Postoperatif Ekstübasyon Kriterleri}

KABG cerrahisinden sonra yoğun bakıma alınan hastaların ekstübasyon kararı hastaya özel olarak bir kardiyovasküler cerrah ile birlikte hastanın takibini yapan yoğun bakım hemşiresi tarafından verildi. Vücut sıcaklığı $>35^{\circ} \mathrm{C}$, uyanık, koopere, hemodinamik olarak stabil olan ve arteriyel kan gazı değerleri $\mathrm{FiO} 2<0,5, \mathrm{pH}>7,30, \mathrm{pO} 2>60, \mathrm{pCO} 2<55$ olan hastalar ekstübasyona uygun olarak kabul edildi. Weaning döneminde SIMV (synchronized intermittent mandatory ventilation) ve CPAP (continuous positive airway pressure) modları kullanılıp, arteriyel kan gazı kontrolü ile y-konneksiyon sonrası ekstübasyon yapıldı. Ameliyat sonrası yetersiz doku perfüzyonu belirtileri bulunan hemodinamik olarak stabil olmayan, iki veya daha fazla inotrop ajan intiyacı, IABP veya ventrikül destekleyen cihaz kullanımı olan çoklu organ yetmezliği olan hastalar ekstübasyon için uygun olmayan hastalar olarak kabul edildi.

\section{Parametreler}

Preoperatif dönemde; demografik faktörler, eşlik eden hastalıklar, aile hikayesi, sigara, tütün ve alkol kullanımı, eğitim durumu, önceki kardiyak girişimler, akut medikal problemler, cerrahinin aciliyeti ve enfeksiyon varlığı değerlendirildi. Intraoperatif dönemde değerlendirilen parametreler arasında anestezi ve cerrahi süre, KPB ve aort klempi (AK) süresi, greft sayısı, kullanılan total opioid ve kas gevşetici miktarı, verilen total kristaloid ve kolloid miktarı, transfüzyon intiyacı [ES, TDP, tam kan (TK), trombosit süspansiyonu (TS)], aprotinin ve traneksamik asit kullanımı, farklı anestezi uygulaması olup olmadığı (torakal epidural, deksmedetomidin gibi), en düşük rektal sıcaklık, pompa öncesi ve sonrası en kötü arteriyel kan gazı değerleri, pompa öncesi ve sonrası en düşük ve yüksek $\mathrm{PaO} 2 / \mathrm{FiO} 2$ oranı, en düşük ve yüksek kan glukozu, hipotansiyon, bradikardi veya hemodinamik instabilite varlığı (bazalin \%20 altı veya üstü), en yüksek santral venöz basınç (SVB), internal mammarian arter (IMA) kullanımı, plevranın açııp açılmadığı, intraaortik balon pompası (IABP) kullanımı, vazopressör intiyacı ve süresi (dopamin, adrenalin, dobutamin, enoksimon), kullanılan kardiyopleji tipi, ultrafiltrasyon ve total sirkülatuar arrest uygulanıp uygulanmadığı bulunmaktadır.

Postoperatif dönemde hastaların ilk ekstübasyon zamanı, reentübasyon ihtiyaçları, reeksplorasyon ve kardiyopulmoner resüsitasyon olup olmadığı, total opioid ve sedatif miktarı, hipotansiyon, bradikardi veya hemodinamik instabilite varlığı (bazalin \%20 altı veya üstü), transfüzyon intiyacı, yoğun bakımda en kötü arteriyel kan gazı, en düşük ve yüksek kan glukozu, en yüksek SVB, ekstübasyon öncesi en yüksek ve düşük $\mathrm{PaO} 2 / \mathrm{FiO} 2$ oranı, mekanik ventilasyon, yoğun bakım ve hastanede kalış süreleri, organ disfonksiyonları ve mortalite [cerrahi sırasında veya postoperatif hospitalizasyonda ilk 48 saat dönemindeki eksituslar] analiz edildi.

Bunlara ek olarak, hastaların preoperatif ve postoperatif 1. gün laboratuvar değerleri [Hemoglobin $(\mathrm{Hb})$, hematokrit $(\mathrm{Htc})$, beyaz küre (BK), trombosit, kan üre azotu (BUN), kreatinin $(\mathrm{Kr})$, aspartat ve alanin aminotransferaz (AST, ALT), total protein, albümin, total/direkt bilirubin, protrombin zamanı (PT), international normalized ratio (INR), aktive parsiyel tromboplastin zamanı (aPTZ), sodyum, potasyum, klor, kalsiyum, glukoz ve C-reaktif protein (CRP)] kaydedildi.

\section{İstatistiksel Analiz}

Verilerin analizi SPSS 11.5 (Statistical Package for Social Sciences, SPSS Inc., Chicago, IL, United States) paket programında yapıldı. Sürekli ölçümlü değişkenlerin dağııımının normale uygun olup olmadığı Shapiro-Wilk testi ile araştırıldı. Tanımlayıcı istatistikler sürekli ölçümlü değişkenler için ortalama \pm standart sapma olarak, nominal değişkenler ise vaka sayısı ve (\%) olarak gösterildi. Ekstübasyon süresi 24 saatten az olan grup ile 24 saat ve üzerinde olan grup arasında sürekli ölçümlü değişkenler yönünden istatistiksel olarak anlamlı bir farkın olup olmadığı, student t veya MannWhitney $U$ testi ile değerlendirildi. Kategorik karşılaştırmalar için Pearson ki-kare veya Fisher'in kesin olasılık testi kullanıldı. Sürenin uzaması üzerinde etkili olabileceği düşünülen sürekli ölçümlü risk faktörlerinin etkisi tek değişkenli lojistik regresyon analizi ile araştııılı. Tek değişkenli istatistiksel analizler sonucunda ekstübasyon süresinin uzamasını öngörmede etkili olan veya etkili olabileceği düşünülen risk faktörlerinin çoklu etkileri geriye dönük elemeli çoklu değişkenli lojistik regresyon analizi ile araştırıldı. Her bir risk faktörüne ilişkin odds oranı, \%95 güven aralığı ve önemlilik düzeyi saptandı. $p<0,05$ için sonuçlar istatistiksel olarak anlamlı kabul edildi.

\section{Bulgular}

Her iki gruptaki hastaların demografik verileri benzer bulundu. Eşlik eden hastalıklar açısından değerlendirildiğinde Grup I'de kronik böbrek yetmezliği ve geçirilmiş serebrovasküler olayın (SVO) Grup II'den fazla olduğu görüldü (sırasıyla $p<0,01, p<0,01$ ) (Tablo 1). Hastalar preoperatif kardiyak girişimler ve akut medikal problemler ile cerrahinin aciliyeti yönünden incelendiğinde gruplar arasında anlamlı fark bulunmadı ( $p>0,05)$ (Tablo 2 ve 3 ).

Hastaların anestezi, cerrahi ve KPB süreleri Grup I'de diğer gruba göre anlamlı uzun bulundu $(p<0,01)$. Gruplar intraoperatif kullanılan opioid, kas gevşetici miktarı ile intraoperatif verilen kristaloid, kolloid, ES, TDP, TK ve trombosit süspansiyonunun toplam miktarları açısından fark göstermedi $(p>0,05)$ (Tablo 5). 
Grup I'de 3, Grup II'de 9 hastada intraoperatif dönemde O2 satürasyonunda düșme izlendi $(p<0,01)$. Postoperatif mekanik ventilasyon intiyacı $>24$ saat olan Grup I'deki hastalarda $\mathrm{O} 2$ satürasyonunda düşme daha sık görüldü $(p=0,02)$. Hastaların intraoperatif özellikleri incelendiğinde, postoperatif mekanik ventilasyon intiyacı $>24$ saat olan Grup I'deki hastaların intraoperatif KPR gereksinimi, IABP kullanımı, vazopressör ve ultrafiltrasyon intiyacının Grup II'dekilerden fazla olduğu saptandı (sırasıyla $p<0,01, p<0,01$, $p=0,02$ ve $p=0,02$ ). Grup I'deki hastaların \%40,9'unda, Grup II'dekilerin \%19,7'sinde intraoperatif vazopressör intiyacı olduğu saptandı $(p=0,02)$ (Tablo 6).

Postoperatif mekanik ventilasyon intiyacı >24 saat olan Grup I'deki hastaların Grup II'dekiler ile karșılaştıııldığında daha fazla reeksplorasyon gereksinimleri olduğu saptandı $(p<0,01)$. Postoperatif ilk ekstübasyona kadar dönemde opioid, sedatif ve kas gevşetici kullanımının da Grup I'de fazla olduğu görüldü (sırasıyla $p=0,02, p<0,01$ ve $p=0,01$ ) .

Tablo 1. Grupların demografik özellikleri, eşlik eden hastalıklar, ailesinde koroner arter hastalığı hikayesi olan (n veya Ortalama \pm SD)

\begin{tabular}{|c|c|c|c|}
\hline & Grup I $(n=22)$ & Grup II (n=463) & p değeri \\
\hline Yaş (yıl) & $64,6 \pm 9,6$ & $60,6 \pm 9,8$ & 0,06 \\
\hline Cinsiyet (E/K) & $20 / 2$ & $340 / 123$ & 0,07 \\
\hline VKI $\left(\mathrm{kg} / \mathrm{m}^{2}\right)$ & $26,0 \pm 3,0$ & $26,9 \pm 4,9$ & 0,40 \\
\hline \multicolumn{4}{|l|}{ Eşlik eden hastalıklar } \\
\hline $\begin{array}{l}\text { HT } \\
\text { DM } \\
\text { HL } \\
\text { KOAH } \\
\text { Geçirilmiş MI } \\
\text { Düşük EF ( <\%35) } \\
\text { Geçirilmiş SVO } \\
\text { Geçirilmiş GIA } \\
\text { KBY }\end{array}$ & $\begin{array}{c}17(\% 77,3) \\
7(\% 31,8) \\
9(\% 40,9) \\
0(\% 0,0) \\
5(\% 22,7) \\
0(\% 0,0) \\
5(\% 22,7) \\
0(\% 0,0) \\
8(\% 27,3)\end{array}$ & $\begin{array}{c}278(\% 60,6) \\
182(\% 39,7) \\
264(\% 57,5) \\
22(\% 4,8) \\
96(\% 20,9) \\
7(\% 1,5) \\
21(\% 4,6) \\
3(\% 0,7) \\
35(\% 5,4)\end{array}$ & $\begin{array}{c}0,11 \\
0,46 \\
0,12 \\
0,61 \\
0,79 \\
1,0 \\
\mathbf{0 , 0 0 4} \\
1,0 \\
\mathbf{0 , 0 0 2}\end{array}$ \\
\hline Aile hikayesi & $11(\% 50,0)$ & $230(\% 49,7)$ & 0,97 \\
\hline
\end{tabular}

EF: ejeksiyon fraksiyonu, DM: diabetes mellitus, HT: hipertansiyon, KBY: kronik böbrek yetmezliği, KOAH: kronik obstrüktif akciğer hastalığı, Mi: miyokard infarktüsü, SVO: serebrovasküler olay, GiA: geçici iskemik atak, VKi: vücut kitle indeksi

Tablo 2. Hastaların preoperatif akut medikal problemleri (n)

\begin{tabular}{lcc}
\hline & Grup I (n=22) & Grup II (n=463) \\
\hline Cerrahiden 1 saat önce KPR gerektiren kardiyak arrest & $1(\% 4,5)$ & $1(\% 0,2)$ \\
IABP kullanımı & $0(\% 0,0)$ & $1(\% 0,2)$ \\
İntravenöz heparin veya nitrogliserin kullanımı & $0(\% 0,0)$ & $13(\% 2,8)$ \\
30 gün içinde Mi geçirme & $2(\% 9,1)$ & $45(\% 9,7)$ \\
Aritmi varlığı & $1(\% 4,5)$ & $13(\% 2,8)$ \\
Enfeksiyon varlığı & $2(\% 9,1)$ & $1(\% 0,2)$ \\
Intravenöz heparin veya nitrogliserin kullanımı + 30 gün içinde Mi geçirme & $0(\% 0,0)$ & $1(\% 0,2)$ \\
30 gün içinde Mi geçirme + enfeksiyon varlı̆̆ı & $0(\% 0,0)$ & $1(\% 0,2)$ \\
Toplam sayı & 6 & 76 \\
\hline
\end{tabular}

IABP: intraaortik balon pompası, KPR: kardiyopulmoner resüsitasyon, Mi: miyokard infarktüsü

Tablo 3. Cerrahinin aciliyeti ( $n$ )

\begin{tabular}{lccc} 
& Grup I (n=22) & Grup II (n=463) & p değeri \\
\hline Acil cerrahi & $2(\% 9,1)$ & $9(\% 1,9)$ & $0,08^{1}$ \\
Elektif cerrahi & $20(\% 90,9)$ & $454(\% 98,1)$ & \\
\hline
\end{tabular}

1-Fisher'in kesin olasılık testi kullanıldı 
Tablo 4. Anestezi ve cerrahi sürele ile greft saylları (Ortalama \pm SD)

\begin{tabular}{lccc}
\hline & Grup I (n=22) & Grup II (n=463) & p değeri \\
\hline Anestezi süresi (dk) & $294,4 \pm 48,0$ & $273,4 \pm 46,8$ & $<, 01$ \\
Cerrahi süre (dk) & $239,4 \pm 54,6$ & $201,6 \pm 42,0$ & $<\mathbf{0 1}$ \\
KPB süresi (dk) & $98 \pm 32,5$ & $72 \pm 24,1$ & $<0, \mathbf{0 1}$ \\
AK süresi (dk) & $40,1 \pm 14,6$ & $34,8 \pm 14,1$ & 0,06 \\
Greft sayısı (n) & $3,5 \pm 1,0$ & $3,2 \pm 0,9$ & 0,23 \\
\hline
\end{tabular}

AK: aorta klempi, KPB: kardiyopulmoner baypas

Tablo 5. Intraoperatif kullanılan ilaç ve kan ürünleri miktarları

\begin{tabular}{lccc}
\hline & Grup I (n=22) & Grup II (n=463) & p değeri \\
\hline Fentanyl (mcg) & $4219 \pm 915,5$ & $3888 \pm 925,2$ & 0,10 \\
Kas gevşetici (mg) & $26,5 \pm 7,3$ & $28 \pm 5,7$ & 0,26 \\
Kristaloid (mL) & $1727 \pm 751,6$ & $1546 \pm 630,7$ & 0,19 \\
Kolloid (mL) & $500 \pm 0,0$ & $502 \pm 32,8$ & 1,00 \\
Eritrosit süspansiyonu (ü) & $2,2 \pm 0,83$ & $2,0 \pm 0,34$ & 0,78 \\
Taze donmuş plazma (ü) & $1,2 \pm 0,70$ & $1,4 \pm 0,83$ & 0,45 \\
Tam kan (ü) & $2,3 \pm 0,67$ & $1,9 \pm 0,59$ & 0,06 \\
Trombosit süspansiyonu (ü) & 2,0 & 1,0 & 0,31 \\
Aprotinin kullanımı (n) & 4 & 47 & 0,23 \\
Traneksamik asit kullanımı (n) & 3 & 45 & 0,55
\end{tabular}

Tablo 6. Hastaların intraoperatif hemodinamik özellikleri veya metabolik instabilite insidansları

\begin{tabular}{|c|c|c|c|}
\hline & Grup I ( $n=22)$ & Grup II $(n=463)$ & p değeri \\
\hline En yüksek kan glukozu (mg/dL) & $190 \pm 46,4$ & $176 \pm 40,8$ & 0,14 \\
\hline En yüksek SVB (mmHg) & $11,3 \pm 3,3$ & $9,9 \pm 2,9$ & 0,03 \\
\hline Hipotansiyon varlığı (n) & $14(\% 70)$ & $257(\% 59,4)$ & 0,34 \\
\hline Bradikardi varlığı (n) & $15(\% 75)$ & $245(\% 57)$ & 0,12 \\
\hline $\begin{array}{l}\text { Yeni gelişen aritmi } \\
\text { AF }(n) \\
\operatorname{VF}(n) \\
\text { Asistoli }(n) \\
\text { AV blok (n) }\end{array}$ & $\begin{array}{c}5(\% 22,7) \\
5 \\
0 \\
0 \\
0\end{array}$ & $\begin{array}{c}46(\% 10) \\
40 \\
3 \\
1 \\
1\end{array}$ & 0,06 \\
\hline Vazopressör kullanımı (n) & $9(\% 40,9)$ & $91(\% 19,7)$ & 0,02 \\
\hline Antihipertansif kullanımı (n) & $19(\% 86,4)$ & $399(\% 87,1)$ & 0,91 \\
\hline Ultrafiltrasyon (n) & $3(\% 13,6)$ & $15(\% 3,3)$ & 0,02 \\
\hline
\end{tabular}

AF: atriyal fibrilasyon, AV blok: atriyoventriküler tam blok IABP: intraaortik balon pompası, IMA: internal mammarian arter, KPR: kardiyopulmoner resüsitasyon, SVB: santral venöz basınç, VF: ventriküler fibrilasyon 
Hipotansiyon ve taşikardi sıklığı Grup I'de anlamlı olarak fazlaydı (sırasıyla $p=0,01$ ve $p=0,03$ ). Grup l'in postoperatif KPR gereksiniminin Grup II'den fazla olduğu görüldü $(p<0,01)$ (Tablo 7).

Mekanik ventilasyon intiyacı >24 saat olan hastalarda postoperatif dönemde ekstübasyona kadar TDP ve TK kullanımının daha fazla olduğu saptandı (sırasıyla $p<0,01$ ve $p=0,03)$. Postoperatif arteriyel kan gazı değerleri incelendiğinde, klinik olarak anlamlı olmamakla birlikte gruplar arasında $\mathrm{pH}$ ve baz açığı bakımından anlamlı fark bulundu $(p=0,01$, her ikisi için). Değerlendirilen diğer postoperatif parametrelerden en düşük kan glukozu, en yüksek SVB ve oranları açısında gruplar arasında anlamlı fark mevcuttu ( $p<0,01$, tüm karşılaştırmalar için) (Tablo 8).

Hastalar postoperatif organ disfonksiyonları yönünden incelendi. Mekanik ventilasyon ihtiyacı >24 saat olan Grup

Tablo 7. Hastaların postoperatif reentübasyon ve reeksplorasyon sıkıkları, ilaç kullanımları ve hemodinamik instabilite insidansları ( $\mathrm{n}$ veya Ortalama \pm SD)

\begin{tabular}{|c|c|c|c|}
\hline & Grup I (n=22) & Grup II $(n=463)$ & p değeri \\
\hline Reentübasyon sıklığı (n) & $0(\% 0,0)$ & $6(\% 1,3)$ & \\
\hline Reeksplorasyon sıklığı (n) & $4(\% 18,2)$ & $11(\% 2,4)$ & 0,003 \\
\hline Opioid kullanımı (n) & $16(\% 72,7)$ & $216(\% 47,1)$ & 0,02 \\
\hline Opioid miktarı (mcg) & $474,3 \pm 573,0$ & $170,3 \pm 131,8$ & 0,019 \\
\hline Sedatif kullanımı (n) & $17(\% 77,3)$ & $216(\% 46,9)$ & 0,005 \\
\hline Sedatif miktarı (mg) & $13,2 \pm 16,9$ & $7,7 \pm 4,6$ & 0,005 \\
\hline Kas gevşetici kullanımı (n) & $2(\% 9,1)$ & $6(\% 1,3)$ & 0,01 \\
\hline Kas gevşetici miktarı (mg) & $48,6 \pm 58,2$ & $25 \pm 41,9$ & 0,26 \\
\hline Hipotansiyon varliğı (n) & $12(\% 60)$ & $136(\% 31,6)$ & 0,01 \\
\hline Hipertansiyon varlığı (n) & $15(\% 75)$ & $269(\% 62,7)$ & 0,27 \\
\hline Bradikardi varlığı (n) & $4(\% 20)$ & $51(\% 11,9)$ & 0,28 \\
\hline Taşikardi varlığı (n) & $17(\% 85)$ & $256(\% 59,7)$ & 0,03 \\
\hline KPR uygulanımı (n) & $6(\% 27,3)$ & $11(\% 2,4)$ & $<0,01$ \\
\hline \multicolumn{4}{|l|}{ KPR: kardiyopulmoner resüsitasyon } \\
\hline & Grup I (n=22) & Grup II (n=463) & p değeri \\
\hline Eritrosit süspansiyonu (mL) & $596,8 \pm 501,2$ & $453,9 \pm 322,7$ & 0,29 \\
\hline Taze donmuş plazma (mL) & $1439,1 \pm 1564,7$ & $544,5 \pm 276,8$ & $<0,01$ \\
\hline Tam kan (mL) & $1928,8 \pm 2507,3$ & $672,0 \pm 346,4$ & 0,03 \\
\hline Trombosit süspansiyonu (mL) & $82,5 \pm 45,9$ & $82,5 \pm 45,9$ & 1,00 \\
\hline $\mathrm{pH}$ & $7,43 \pm 0,1$ & $7,48 \pm 0,1$ & 0,01 \\
\hline $\mathrm{pCO}_{2}(\mathrm{mmHg})$ & $34,0 \pm 5,2$ & $33,5 \pm 5,0$ & 0,67 \\
\hline $\mathrm{pO}_{2}(\mathrm{mmHg})$ & $199,6 \pm 105,3$ & $216,3 \pm 9,6$ & 0,38 \\
\hline $\mathrm{BE}$ & $-0,0 \pm 7,1$ & $1,7 \pm 2,6$ & 0,01 \\
\hline $\mathrm{SaO}_{2}(\%)$ & $97,1 \pm 8,5$ & $99,2 \pm 1,6$ & 0,10 \\
\hline Laktat (mmol/L) & $3,2 \pm 2,5$ & $2,2 \pm 0,9$ & 0,29 \\
\hline En düşük kan glukozu (mg/dL) & $111,4 \pm 34,9$ & $142,0 \pm 35,7$ & 0,004 \\
\hline En yüksek kan glukozu (mg/dL) & $259,8 \pm 72,0$ & $250,6 \pm 61,7$ & 0,73 \\
\hline En yüksek SVB (mmHg) & $13,5 \pm 5.5$ & $9.8 \pm 2.6$ & 0.00 \\
\hline En yüksek $\mathrm{PaO} 2 / \mathrm{FiO} 2$ & $371.8 \pm 163.5$ & $417.3 \pm 153.5$ & 0.17 \\
\hline En düşük $\mathrm{PaO} 2 / \mathrm{FiO} 2$ & $192.2 \pm 111.5$ & $195.8 \pm 80.3$ & $<0.01$ \\
\hline
\end{tabular}

BE: baz açı̆̆ı, FiO2: inspire edilen oksijen fraksiyonu, $\mathrm{pO}_{2}$ : arteriyel oksijen basıncı, $\mathrm{pCO}_{2}$ : arteriyel karbondioksit basıncı, SaO2: arteriyel oksijen satürasyonu, SVB: santral venöz basınç 
I'deki hastalarda \%35, Grup II'de \%5,2 oranında organ disfonksiyonu saptandı $(p<0,01)$. Kardiyak ve solunum sistemine ait komplikasyonlara Grup I'de daha fazla rastlandı (sırasıyla $p<0,01$ ve $p=0,06$ ). En sık rastlanan kardiyak sorunlar arasında atriyal fibrilasyon ve ventriküler taşikardi, solunum sistemine ait sorunlar arasında ise plevral efüzyon, pnömotoraks ve pnömoni vardı. Kardiyak komplikasyon gelişen Grup I'deki hastaların \%80'inde atriyal fibrilasyon (AF), \%20'sinde ventriküler taşikardi (VT) görüldü. Solunum komplikasyonu gelişen Grup I'deki hastaların \% 75'inde plevral effüzyon, \%25'inde pnömoni görüldü. Grup II'deki hastalarda ise \%87,1 AF, \%6,5 VF, \%3,2 VT ve Ml saptand. Grup II'deki solunum komplikasyonları ise \%57,9 plevral efüzyon, \%26,3 pnömotoraks ve \%15,8 pnömoni idi.

Mekanik ventilasyon intiyacı $>24$ saat olan Grup I'deki hastaların cerrahi sırasında veya postoperatif 48 saat içindeki mortaliteleri Grup II'den fazla saptandı $(p<0,01)$. Hastaların hastanede kalış süreleri Grup I'de anlamlı olarak uzun bulundu $(p<0,01)$ (Tablo 9).

Çoklu lojistik regresyon analizine göre mekanik ventilasyon süresinin uzaması üzerinde SVO varlığı, KPB süresi, intraoperatif dönemde $\mathrm{O} 2$ satürasyonunda düşme, sedatif kullanımı ve postoperatif dönemde kullanılan TDP miktarı etkili bulundu. Sürenin uzaması üzerinde en fazla anlamlı etkiye sahip olan risk faktörü postoperatif kullanılan TDP miktarı idi. Diğer koşullar sabit bırakıldığında, kullanılan TDP miktarındaki her bir ünitelik artış mekanik ventilasyon süresinin uzama intimalini 1,003 $(1,002-1,005)$ kat artırmaktaydı $(p<0,001)$. SVO öyküsü olanlarda SVO öyküsü olmayanlara göre mekanik ventilasyon süresinin uzama ihtimali 6,31 $(1,44-27,68)$ kat daha fazla idi $(p=0,015)$. KPB süresindeki her bir dakikalık artış mekanik ventilasyon süresinin uzaması riskini 1,026 $(1,004-$ $1,050)$ kat artırmaktaydı $(p=0,023)$. Yine mekanik ventilasyon süresinin uzama riski sedatif kullanılan olgularda 4,52 (1,22$16,78)$ kat daha fazla idi $(p=0,024)$. Son olarak intraoperatif dönemde oksijen saturasyonunda düşüş görülen olgularda mekanik ventilasyon süresinin uzaması intimali 14,2 (1,32$153,54)$ kat daha fazla idi $(p=0,029)$ (Tablo 10).

\section{Tartışma}

KABG cerrahisi sonrası hastaların çoğu birkaç saat içerisinde ekstübe olmakla birlikte bazı hastaların eksübasyonu gecikebilmektedir. Olumsuz sonuçları bulunan uzamış mekanik ventilasyonun olası önbelirleyiciler ile tespiti sayesinde hastalara preemptif stratejilerin ve postoperatif uygun tedavi yaklaşımlarının sağlanması mümkün olabilir. Uzamış mekanik ventilasyonun net tanımı, görülme sıklığı ve bağımsız önbelirleyicileri hakkında uzlaşmaya henüz varılamamıştır (6,9-20). Yirmi dört saatten uzun süren mekanik ventilasyon ihtiyacını uzamış mekanik ventilasyon olarak tanımladığımız çalışmamızda; preoperatif SVO varlığı, KPB süresi, intraoperatif $\mathrm{O} 2$ satürasyonunda düşme, postoperatif taze donmuş plazma ve sedatif kullanımının KABG sonrası uzamış mekanik ventilasyon için risk faktörleri olduğunu saptadık.

Uzamış entübasyon, havayolu ve akciğere olan travmayı artırmanın yanında kalp debisi ve böbrek perfüzyonunu azaltıp tüp içi aspirasyonun yol açtığı rahatsızlık ve weaning sorunlarına artmış hastane masraflarını eklemektedir. KABG sonrası uzamış mekanik ventilasyonun \%3-9,9 arasında olduğu bildirilmektedir (9-14). Hastanemizde sadece KABG

Tablo 9. Hastaların mortalite insidansları ve hastanede kalış süreleri

\begin{tabular}{lccc}
\hline & Grup I $(\mathbf{n}=\mathbf{2 2})$ & Grup II $(\mathbf{n = 4 6 3 )}$ & p değeri \\
\hline Mortalite $(n)$ & $5(\% 22,7)$ & $11(\% 2,4)$ & $<0, \mathbf{0 1}$ \\
Hastanede kalış süresi & $17,5 \pm 8,3$ & $11,3 \pm 6,4$ & $<0,01$ \\
\hline
\end{tabular}

1-Fisher'in kesin olasılık testi kullanıldı

Tablo 10. Çoklu lojistik regresyon analizine göre >24 saat mekanik ventilasyon zamanı üzerinde en fazla etkiye sahip olan risk faktörlerine ilişkin odds oranları, \%95 güven aralıkları ve önemlilik düzeyleri

\begin{tabular}{lllllc}
\hline Risk & Odds & Wald & p & \multicolumn{2}{c}{ \%95 Güven Aralığı } \\
Faktörleri & Oranı & ístatistiği & değeri & Alt Sınır & Üst Sınır \\
\hline Preoperatif SVO varlığı & 6,310 & 5,962 & 0,015 & 1,438 & 27,685 \\
KPB süresi & 1,026 & 5,145 & 0,023 & 1,004 & 1,050 \\
Intraoperatif SaO2 düşme & 14,23 & 4,791 & 0,029 & 1,320 & 153,537 \\
Postoperatif sedatif kullanımı & 4,520 & 5,078 & 0,024 & 1,217 & 16,784 \\
Postoperatif TDP kullanımı & 1,003 & 19,769 & $<0,001$ & 1,002 & 1,005 \\
\hline
\end{tabular}

KPB: kardiyopulmoner baypas, SVO: serebrovasküler olay, TDP: taze donmuş plazma 
yapılan hastaların \%95,5'inin mekanik ventilasyon ihtiyacı 24 saat altında mekanik ventilasyon ihtiyacı olmakta ve bu hastalarda ameliyattan 11,3 $\pm 6,5$ gün sonra hastaneden taburcu olmaktadır.

Sağlık harcamalarının önemli bir kısmını kapsayan ve sık uygulanan KABG cerrahisinde uzamış mekanik ventilasyon ihtiyacı olacak hastaların tanımlanması ve önleyici stratejilerin belirlenmesi yoğun bakım ve hastanede kalış sürelerini kısaltmak dolayısıyla maliyeti düşürmek açısından oldukça önemlidir. Uzamış mekanik ventilasyon için tanımlanan süre hakkında kesin bir görüş birliği olmamakla birlikte bu süre literatürde 12 saat ile 6 gün arasında değişmektedir (4,5,2125). Biz de klinik pratiğimize en uygun sürenin 24 saat olduğunu düşünerek uzamış mekanik ventilasyon süresini 24 saat olarak kabul ettik.

Bulgularımız tekli lojistik regresyon analizi ile değerlendirildiğinde; uzamış mekanik ventilasyon ihtiyacını öngörmede preoperatif KBY ve SVO varlığı, acil cerrahi, intraoperatif kas gevşetici miktarı, intraoperatif SaO2'de düşme, intra- ve post-operatif KPR gereksinimi, reeksplorasyon, ultrafiltrasyon kullanımı, postoperatif aritmi varlığı, postoperatif IABP ve sedatif kullanımı ile postoperatif sistemik komplikasyon varlığı gibi parametrelerin kullanılabileceği görülmektedir.

Higgins ve arkadaşlarının (26) KABG cerrahisi sonrası yoğun bakım mortalite ve morbiditesini tahmin etmede kullandıkları ICURSS (ICU risk stratification score) skorlamasındaki parametrelerden biri de preoperatif inme varlığıdır. Benzer şekilde, Redmond ve arkadaşları (27), ileri dönük vaka kontrollü çalışmalarında, öncesinde inme geçirmiş kalp cerrahisi hastalarının (bütün grubun \% 7'si) inme geçirmemiş hastalara göre perioperatif nörolojik morbidite insidanslarını \%44'e karşı \%1,4 olarak bildirmişlerdir. Aynı çalışmada, öncesinde inme geçirmiş grubun anesteziden derlenme ve ilk ekstübasyon zamanları daha uzun bulunurken, reentübasyon insidansları da preoperatif hikayesinde inme olmayanlardan yüksek bulunmuştur. Bizim bulgularımız da, preoperatif SVO varlığının tek başına uzamış mekanik ventilasyon insidansını 6,3 kat artırdığını desteklemektedir. KABG cerrahisinin akciğerler üzerindeki olumsuz etkileri ve preoperatif SVO varlığının yol açtığı postoperatif hasta mobilizasyonundaki problemler ile birlikte postoperatif mekanik ventilasyon süresinin uzayabileceği düşünülebilir.

Preoperatif dönemde KBY olan hastalar postoperatif gecikmiş ekstübasyon yönünden yüksek risk taşımaktadır. Çalışmamızda, preoperatif KBY, uzamış mekanik ventilasyon insidansını 6 kat artıran bir risk faktörü olarak bulundu (OR: 6,92). Diyaliz bağımlı hastalarda kardiyak cerrahi sonrası total sıvı dengesinin pozitif oluşu akciğer konjesyonuna bağlı oksijenasyonu bozmakta ve uzamış mekanik ventilasyona neden olabilmektedir (28).
Acil cerrahi genellikle medikal durumu stabil olmayan hastalar için gerektiğinden operatif mortalite ve morbidite artışı beklenebilir. Bu koşullar altında acil gerçekleştirilen KABG cerrahisi yüksek risk taşımaktadır $(26,29)$. Çalışmamızda tekli analiz sonucunda acil cerrahi girişimin uzamış mekanik ventilasyon insidansını 5,02 kat artırdığını gösterdik.

Cislaghi ve arkadaşları (30), uzun KPB zamanını (91 dakika üstü), redo cerrahi, EF <\%30 ve 4 üniteden fazla ES veya TDP transfüzyonu ile birlikte uzamış mekanik ventilasyon için bağımsız önbelirleyiciler olduğunu göstermişler. Çalışmamız uzun KPB zamanını uzamış mekanik ventilasyon için bağımsız bir risk faktörü olarak gösterdi. Ancak gruplar arasında farklılık gösteren anestezi ve cerrahi süreleri tekli ve çoklu regresyon analizi sonucunda önbelirleyici olarak saptanmadı. Çalışmamızda, KPB zamanı uzamış mekanik ventilasyon ihtiyacı olan hastalarda 98 $\$ 32,5$ dakika iken diğer grupta $72 \pm 24,1$ dakika olarak bulundu. Uzun cerrahi ve KPB zamanı, deprese ventriküler fonksiyonla birlikte oksijenasyonu ve kardiyak fonksiyonu kötüleştirebilir ve meydana gelen inflamatuar reaksiyonu şiddetlendirebilir $(30,31)$. KPB sırasındaki fizyolojik olmayan dolaşım, hastaların periferik doku perfüzyonunu olumsuz etkilemektedir $(32,33)$. $\mathrm{KPB}$, polimorfonükleer lökositleri ve kompleman sistemini önemli ölçüde aktive etmektedir. Iskemi-reperfüzyon hasarı süresince polimorfonükleer lökositlerin koroner ve akciğer endotelindeki inflamasyonda ciddi rol oynadıklarını gösterilmiştir (34). Çalışmamızda, KPB süresinin uzamış mekanik ventilasyon için risk faktörü olarak bulunması, KPB'nin akciğerler üzerine bilinen olumsuz etkileri nedeniyle şaşırtıcı değildir. Çalışmamızda, intraoperatif hemodinamik parametrelerin değerlendirilmesi sonucu sadece intraoperatif O2 satürasyonunun \%90'ın altına düşmesi uzamış mekanik ventilasyon insidansını 14,2 kat artıran güçlü bir önbelirleyici olarak bulundu. Literatürde bu konuda herhangi bir çalışmaya rastlanmamıştır.

Tekli regresyon analizinde intraoperatif IABP intiyacı ve intraoperatif vazopressör kullanımında artma uzamış mekanik ventilasyon ile sonuçlandı (OR değerleri sırasıyla 34,0 ve 2,81). Benzer şekilde, Natarajan ve arkadaşları (35), uzun KPB zamanı ve IABP kullanımının uzamış mekanik ventilasyon için önbelirleyici olduğunu bildirmişler ve pompadan çıkmadan önce yerleştirilen IABP'nin KPB süresini uzattığını savunmuşlardır. Perioperatif kalp yetersizliği gelişmesi, ekstübasyon için gerekli olan kriterlerden hemodinamik stabiliteyi sağlayamadığından mekanik ventilasyon nedeni olacaktır. Bütün bu risk faktörleri ile ilişkili olarak intraoperatif KPR uygulaması, uzamış mekanik ventilasyon ihtiyacı olan hastalarda tekli regresyon analiz sonucunda önbelirleyici olarak bulunmuştur (OR: 11). Intraoperatif vital bulgulardaki değişikliklerden aritmi varlığının düşük OR değeri nedeniyle zayıf bir önbelirleyici olabileceğini düşündük. 
Çalışmamızda, tekli regresyon analizi sonucunda intraoperatif ultrafiltrasyon ihtiyacının uzamış mekanik ventilasyon insidansını artırdığını gördük (OR: 4,7). Ancak çoklu analizde bağımsız bir önbelirleyici olarak bulmadık.

Postoperatif TDP ve sedatif kullanımının çoklu regresyon analizinde KABG sonrası uzamış mekanik ventilasyon için önbelirleyici olabileceğini gösterdik. Postoperatif opiod ve kas gevşetici kullanımının ise uzamış mekanik ventilasyon grubunda diğer grup ile karşılaştırıldığında anlamlı olarak fazla olduğu tespit edilmekle beraber çoklu regresyon analizi sonucunda önbelirleyici olarak bulmadık. Yoğun bakım hastalarının sedasyonu için kullanılan sedatif, opioid veya nöromusküler ajanların mümkün olan en düşük dozlarda kullanımı ve bu ajanlara günlük ara verilmesinin mekanik ventilasyon ve hastanede kalış sürelerini kısalttığı belirtilmektedir (36). Gecikmiş ekstübasyon görülen hasta grubumuzda kardiyak cerrahi sonrası bu ilaçların daha fazla kullanımı sonucu mekanik ventilasyon süresinin uzaması da şaşırtıcı değildir. Çalışmamızda postoperatif sedatif kullanımı çoklu regresyon analizi ile güçlü bir önbelirleyici olarak bulduk (OR: 4,5). Mekanik ventilasyon süresi uzayan hastaların sedatif kullanımları da artacağından çıkan bu sonuç tartışmalıdır. KABG cerrahisinde kan ve kan ürünü transfüzyonu oldukça yaygın kullanılmaktadır. Scott ve arkadaşları (37), 2008 yılında kalp cerrahisi geçiren 1746 hastadan, kan ve kan ürünü kullanan 1069 hastanın ekstübasyon zamanını (8 saat'e karşı 4,3 saat) daha uzun bulmuştur. Aynı çalışmada transfüzyon alan grupta postoperatif nörolojik, gastrointestinal komplikasyonlar, böbrek yetmezliği, enfeksiyon daha fazla görülürken transfüzyon alan hastaların karakteristik özellikleri ise yaşlı, ince yapılı, preoperatif hematokrit değeri düşük ve daha çok kadın cinsiyette olmaları idi. Sonuçlarımız daha önceki çalışmalarla benzer bulunmuştur. Transfüzyon gereksinimi yetersiz hemostazı ve stabil olmayan hemodinamiyi yansıtmaktadır. Transfüzyon ihtiyacı ve reeksplorasyon birbirlerini sinerjistik etkilemektedir. Artmış transfüzyon ihtiyacı orta veya ciddi kanama ile ilişkili iken reeksplorasyon cerrahi teknikteki güçlük ve yüksek kanama riski ile beraberdir. Çalışmamızda literatür ile uyumlu olarak tekli regresyon analizi sonucunda KABG cerrahisi sonrasında reeksplorasyonun uzamış mekanik ventilasyon insidansını 9,1 kat artırdığını gösterdik.

Uzamış mekanik ventilasyon gereksinimi olan hastaların postoperatif hemodinamik durumlarını etkileyen kalp hızı ve kan basıncı değerleri tekli regresyon analizi ile değerlendirildiğinde postoperatif yeni gelişen aritmi ve hipotansiyon varlığının güçlü bir önbelirleyici olabileceğini bulduk (OR değerleri sırasıyla 5,0 ve 3,3).

Çalışmamızda postoperatif bakılan ilk kan gazı değerlerinde pH ve baz açığı; en düşük kan gkukozu ve en düşük $\mathrm{PaO} 2 / \mathrm{FiO} 2$ oranı gruplar arasında farklılık gösterdi, ancak bu parametreler regresyon analizi sonucunda uzamış mekanik ventilasyon için önbelirleyici olarak bulunmadı. Nakasuji ve arkadaşları (28), PaO2/FiO2 oranının daha düşük olmasını perioperatif kardiyak disfonksiyon sonucu gelişen akciğer konjesyonuna bağlı olabileceğini savunmuşlardır. Hastalarımızın postoperatif birinci gün bakılan BUN ve kreatinin değerleri uzamış mekanik ventilasyon ihtiyacı olanlarda anlamlı yükseklik gösterse de önbelirleyici olamamıştır. Bu değerlerin yükselmesi belki de postoperatif renal yetmezlik gelişimini ve beraberinde görülebilecek solunumsal problemleri işaret edebilir.

Tekli regresyon analizinde postoperatif sistemik komplikasyon varlığını postoperatif mekanik ventilasyon süresini uzatan bir risk faktörü olarak bulduk $(O R$ 9,3). Kanama yol açtığı hemodinamik instabiliteden dolayı ekstübasyona izin vermemektedir. Postoperatif nörolojik komplikasyonlar, uzamış mekanik ventilasyonun önemli nedenlerindendir. Roach ve arkadaşlarının (38), ileri dönük ve çok merkezli çalışmasında KABG sonrası 2108 hastanın 129'unda postoperatif nörolojik değişikler bulmuştur. Çalışmamızda ise hastaların tamamının $\% 2,1$ 'inde, uzamış entübasyon gerektiren hastaların ise \%1,8'inde nörolojik komplikasyon bulduk.

Kalp cerrahisi sonrası pnömoni gelişen hastaların diyaliz, reentübasyon, trakeostomi ve IABP ihtiyaçları mevcuttur. Bouza ve arkadaşlarının (39), çalışmalarında, hastaların 7 günden fazla entübe kalmalarının pnömoni insidansını \%44,1'e çıkarttığını belirtmişlerdir. Hastalarımızın \%4,8'inde akciğer komplikasyonları görüldü. Çalışmamız sonucunda uzamış mekanik ventilasyon gereken hastaların \%4,2'sinde akciğer komplikasyonları görülürken çoğunu pnömoni oluşturuyordu.

Akut böbrek yetmezliği, KPB ile birlikte olan kalp cerrahisinde postoperatif görülen ciddi komplikasyonlardan biridir. Bununla birlikte, \%1 veya 2 gibi küçük bir grupta diyaliz gerektiren akut böbrek yetmezliği gelişmektedir (40). Çalışmamızda KABG cerrahisi sonrasında yeni gelişen renal komplikasyon insidansı \%5,9 iken, uzamış mekanik ventilasyon ihtiyacı olan hastaların \%5,5'inde görüldü. Renal komplikasyon görülen hastaların \%28,6'sında çeşitli nedenlerle diyaliz intiyaçları olurken \%64,3'ü akut böbrek yetmezliği nedeniyle diyalize alındılar.

Uzamış mekanik ventilasyon ihtiyacı olan yirmi iki hastamızın beşi $(\% 22,7)$ cerrahi sırasında veya postoperatif 48 saat içinde eksitus oldu. Yirmi dört saatten az mekanik ventilasyon ihtiyacı olan grubun ise mortalitesi $\% 2,4$ idi. Bu sonuç uzamış entübasyon ve dolayısıyla mekanik ventilasyonun tek başına mortaliteyi artırdığını göstermemekle birlikte KABG cerrahisi geçirmiş hastalar arasında artmış morbidite ve mortaliteye sahip hasta grubunun belirlenmesi açısından önemlidir. Benzer şekilde Natarajan ve arkadaşlarının (35), KABG sonrası uzamış 
mekanik ventilasyon intiyacı olan hastaların mortalitesini \%36,3 olarak bulmuştur.

Çalıșmamızın bazı kısıtlılıkları vardı. En önemli etken yetersiz hasta sayısı nedeniyle günlük pratiğimizi değiștirebilecek bir genelleme yapılmasındaki güçlüktür. Bununla birlikte, hastanemizin yapılanması nedeniyle daha yüksek riskte hastaların ameliyat ediliyor olması sonuçlarımızın bize göre daha az komplike, daha az sayıda hasta alan ve aynı zamanda farklı pratik uygulamaya sahip merkezlerden farklı olmasına neden olmuş olabilir.

KABG cerrahisi geçiren erişkin hastaların uzamış mekanik ventilasyon önbelirleyicilerini göstermeyi hedeflediğimiz çalıșmamızda preoperatif SVO varlığı, KPB süresi, intraoperatif $\mathrm{O} 2$ satürasyonunda düșme, postoperatif TDP transfüzyonunun ve sedatif kullanımının uzamış mekanik ventilasyon için güçlü önbelirleyiciler olabileceği saptanmıștır.

\section{Kaynaklar}

1. Society of Thoracic Surgeons National database. Erişim (http.// www.ctsnet.org. Accessed) Erişim tarihi: June 13, 2002.

2. Doering LV, Imperial- Perez F, Monsein S. Preoperative and postoperative predictors of early and delayed extubation after coronary artery bypass surgery. Am J Crit Care 1998;7:37-44.

3. Wong DT, Cheng DC, Kustra R, Tibshirani R, Karski J, Carroll-Munro J, et al. Risk factors of delayed extubation, prolonged length of stay in the intensive care unit and mortality in patients undergoing coronary artery bypass graft surgery with fast track cardiac anesthesia. Anesthesiology 1999:91:936-44.

4. Spivack SD, Shinozaki T, Albertini JJ, Deane R. Preoperative prediction of postoperative respiratory outcome: coronary artery bypass grafting. Chest 1996;109:1222-30.

5. Thompson MJ, Elton RA, Sturgeon KR, Manclark SL, Fraser AK, Walker WS et al. The Edinburgh Cardiac surgery score survival prediction in the long stay ICU cardiac surgical patients. Eur J Cardiothorac Surg 1995;9:419-25.

6. Habib RH, Zacharias A, Engoren M. Determinants of prolonged mechanical ventilation after coronary artey bypass grafting. Ann Thorac Surg 1996;62:116471.

7. Butler J, Chong GL, Pillai R, Westaby S, Rocker GM. Early extubation after coronary artery bypass surgery: effects on oxygen flux and hemodynamic variables. $J$ Cardiovasc Surg (Torino) 1992;33:276-80.

8. Gall SA, Olsen CO, Reves JG, Mclntyre RW, Tyson Jr GS, Davis JW, et al. Beneficial effects of endotracheal extubation on ventricular performance. J Thorac Cardiovasc Surg 1988;95:819-27.

9. Rajakaruna C, Rogers CA, Angelini GD, Ascione R. Risk factors for and economic implications of prolonged ventilation after cardiac surgery. J Thorac Cardiovasc Surg 2005;130:1270-7.
10. Serrano N, García C, Villegas J, Huidobro S, Henry CC, Santacreu R, Mora ML; Epidemiological Project for ICU Research and Evaluation (EPICURE). Prolonged intubation rates after coronary artery bypass surgery and ICU risk stratification score. Chest 2005;128:595-601.

11. Oliver WC Jr, Nuttall GA, Orszulak TA, Bamlet WR, Abel MD, Ereth MH, et al. Hemofiltration but not steroids results in earlier tracheal extubation following cardiopulmonary bypass: a prospective randomized double-blind trial. Anesthesiology 2004;101:327-39.

12. Pappalardo F, Franco A, Landoni G, Cardano P, Zangrillo A, Alfieri O. Long-term outcome and quality of life of patients requiring prolonged mechanical ventilation after cardiac surgery. Eur J Cardiothorac Surg 2004;25:548-52.

13. Dunning J, Au J, Kalkat M, Levine A. A validated rule for predicting patients who require prolonged ventilation post cardiac surgery. Eur J Cardiothorac Surg 2003:24:270-6.

14. Ranucci M, Bellucci C, Conti D, Cazzaniga A, Maugeri B. Determinants of early discharge from the intensive care unit after cardiac operations. Ann Thorac Surg 2007:83:1089-95.

15. Gopalan PD, Burrows RC. Critical care of the vascular surgery patient. Crit Care Clin 2003;19:109-25

16. Branca P, McGaw P, Light R. Factors associated with prolonged mechanical ventilation following coronary artey bypass surgery. Chest 2001;119:537-46.

17. Engoren M, Buderer NF, Zacharias A Long-term survival and health status after prolonged mechanical ventilation after cardiac surgery. Crit Care Med 2000:28:2742-9

18. Lo Cicero J 3rd, McCann B, Massad M, Joob AW. Prolonged ventilatory support after open-heart surgery. Crit Care Med 1992;20:990-2

19. Peters RM, Brimm JE, Utley JR. Predicting the need for prolonged ventilatory support in adult cardiac patients. J Thorac Cardiovasc Surg 1979:77:175-82.
20. Prakash O, Jonson B, Meij S, Bos E, Hugenholtz PG, Nauta J, et al. Criteria for early extubation after intracardiac surgery in adults. A nesth Analg 1977;56:703-8.

21. Kollef $\mathrm{MH}$, Wragge $\mathrm{T}$, Pasque $\mathrm{C}$. Determinants of mortality and multiorgandysfunction in cardiac surgery patients requiring prolonged mechanical ventilation. Chest 1995;107:1395-401.

22. Geraci JM, Rosen AK, Ash AS, McNiff KJ, Moskowitz MA. Predicting the occurrence of adverse events after coronary artery bypass surgery. Ann Intern Med 1993;118:18-24

23. Silbert BS, Santamaria JD, O'Brien JL, Blyth CM, Kelly WJ, Molnar RR. Early extubation following coronary artery bypass surgery. Chest 1998;113:1481-8.

24. Knapik P, Ciesla D, Borowik D, Czempik $P$, Knapik T. Prolonged ventilation post cardiac surgery - tips and pitfalls of the prediction game. J Cardiothorac Surg 2011;6:158

25. Saleh HZ, Shaw M, Al-Rawi O, Yates J, Pullan DM, Chalmers JA, et al. Outcomes and predictors of prolonged ventilation in patients undergoing elective coronary surgery. Interact CardioVasc Thorac Surg 2012;15:51-6.

26. Higgins TL, Estafanous FG, Loop FD, Beck GJ, Blum JM, Paranandi L. Stratification of morbidity and mortality outcome by preoperative risk factors in coronary artery bypass patients: a clinical severity score. JAMA 1992:267:2344-8.

27. Redmond JM, Greene PS, Goldsborough MA, Cameron DE, Stuart RS, Sussman MS, et al. Neurologic injury in cardiac surgical patients with history of stroke. Ann Thorac Surg 1996:61:42-7.

28. Nakasuji M, Nishi S, Nakasuji K, Hamaoka $\mathrm{N}$, Ikesthia K, Asada A. Duration of dialysis is a significant predictor of prolonged postoperative mechanical ventilation in dialysis-dependent patients undergoing cardiac surgery. Anesth Analg 2006;102:2-7.

29. Kurki TS, Kataja M. Preoperative prediction of postoperative morbidity in coronary artery bypass grafting. Ann Thorac Surg 1996:61:1740-5 
30. Cislaghi F, Condemı AM, Corona A. Predictors of prolonged mechanical ventilation in a cohort of 3269 CABG patients. Minerva Anestesiol 2007;73:615-21

31. Widyastuti $Y$, Stenseth R, Pleym H, Wahba A, Videm V. Peroperative and intraoperative determinants for prolonged ventilation following adult cardiac surgery. Acta Anaesthesiology Scand 2012;56:190-9.

32. Rothenburger M, Tjan TD, Schneider $M$, Berendes E, Schmid C, Wilhelm $M J$ et al. The impact of the pro- and anti-inflammatory immune response on ventilation time after cardiac surgery. Cytometry B Clin Cytom 2003;53:70-4.

33. Levy JH, Tanaka KA. Inflammatory response to cardiopulmonary bypass. Ann Thorac Surg 2003;75:S715-20.
34. Herskowitz A, Mangano DT. Inflammatory cascade. A final common pathway for perioperative injury. Anesthesiology 1996;85:957-60

35. Natarajan K, Patil S, Lesley N, Ninan B. Predictors of prolonged mechanical ventilation after on-pump coronary artery bypass grafting. Ann Card Anaesth 2006;9:31-6

36. Kress JP, Pohlman AS, O'Connor MF, Hall JB. Daily interruption in critically ill patients undergoing mechanical ventilation. N Engl J Med 2000;342:1471-7.

37. Scott B, Seifert F, Grimson R. Blood transfusion is associated with increased resource utilisation, morbidity and mortality in cardiac surgery. Ann Card Anesth 2008;11:15-9.
38. Roach GW, Kanchuger M, Mangano CM. Adverse cerebral outcomes after coronary bypass surgery. Multicenter Study of Perioperative Ischemia Research Group and the Ischemia Research and Education Foundation Investigators. N Engl J Med 1996;335:1857-63.

39. Bouza E, Pérez A, Muñoz $P$, Jesús Pérez M, Rincón C, Sánchez C, et al. Ventilator-associated pneumonia after heart surgery: a prospective analysis and the value of surveillance. Crit Care Med 2003;31:1964-70.

40. Abel RM, Buckley MJ, Austen WG, Barnett GO, Beck CH Jr, Fischer JE. Etiology, incidence, and prognosis of renal failure following cardiac operations. Results of prospective analysis of 500 consecutive patients. J Thorac Cardiovasc Surg 1976;71:323-33. 